Bulletin No. I gives an account of the methods which were actually used by the forest officers in charge of the survey. These methods are based on the measurement of well-stocked sample plots of woods of various agés and on all classes of soils. Five working parties were employed; the actual measurements being made by women assistants under the supervision of a skilled officer who inspected the woods and selected the plots. This bulletin is clearly written, and will prove useful to private owners wishing to lay out sample plots by means of which they will be enabled to measure the volume and increment of their own woods by official and scientific methods.

The third bulletin deals with the results of the survey which was restricted to pure woods of conifers. It furnishes us for the first time with accurate yieldtables of larch, Scots pine, and spruce based on accurate measurements of these species in British plantations. Hitherto we were dependent on Continental yield-tables, which apply only very approximately to this country. Provisional tables for Douglas fir, Japanese larch, and Corsican pine are also given in the bulletin. The yield-tables are of the usual kind, giving for various qualities of soils the average height and diameter of the trees and the number of stems and volume of timber per acre, with other figures, corresponding to ages of $10, r_{5}, 20, \ldots$. Jon vears. Any wood, provided its age is known, can be allocated to its proper quality class by the average height of the trees, as it is well established that in a fully stocked wood of any species the volume at a given age is in direct relation with the mean height.

A considerable part of Bulletin No. 3 is taken up with a discussion on the factors of climate and soil in relation to the growth of species, like Scots pine, larch, and spruce. This branch of the subject is very important, and deserves much more extended investigation than was possible in this preliminary survey.

Bulletin No. 2, prepared by Dr. J. W. Munro, the entomologist employed by the Forestry Commission, is based on a survey of the insect conditions of coniferous woods in seventeen districts of the United Kingdom in 1919. This survey was rendered necessary by the great increase in harmful insects occasioned by the heavy fellings of timber during the years of the war. Owing to the shortage of labour it was impossible to clear the ground of the branches and débris which, with the stumps of the trees, form the main breeding-grounds of these pests. Dr. Munro investigated the ravages of fifteen species of insects, and reports that coniferous, woods generally are in a very unhealthy state. Young plantations on the site of, or near, a felled area suffer most. This bulletin is well illustrated, and Dr. Munro's remarks on measures of prevention should be studied carefully by all foresters engaged in the formation of new plantations.

\title{
Greenland in Europe. ${ }^{1}$
}

\section{By David MacRitchie.}

A T the present day the name "Greenland" is A limited to the great island lying to the east of Arctic America. Formerly, however, it included an undefined territory of Arctic and sub-Arctic Europe, extending eastward, according to some estimates, into north-western Siberia. Sir William Martin Conway has shown (Hakluyt Series, I904) that during the seventeenth century, in Britain and the neighbouring countries, "Greenland" primarily denoted Spitsbergen. Even in the year 1812 the leading London publishers were selling a school-book which, ignoring the word "Spitsbergen", altogether, applied to that group of islands the sole name of "Greenland."

But so early as the time of the Norman conquest of England a German chronicler, a minor canon of the Cathedral of Bremen, widely known as "Adam of Bremen," had recorded the existence of a Greenland in Northern Europe. There is good reason for assuming that the region he had in view was the Kola Peninsula and a good deal of contiguous territory. He states that those Greenlanders were caerulei (blue men), and that they were cruel, "troubling seafarers by predatory attacks "--from which it may be inferred that they were themselves seafarers. In passing, it may be pointed out that at a very. much earlier date the Romans had noted the existence of a caste of caerule $i$ in the British Isles: In both cases the name probably arose from the custom of painting or tattooing with blue pigments.

The assumption that Adam of Bremen's "Greenland" was the Kola Peninsula and the parts adjoining receives confirmation from a statement made in r 430 by a Danish traveller and writer of the name of Claus Claussön, Latinised Claudius Clavus; for he tells us, from personal knowledge, that at that time "the infidel Karelians daily come to Greenland in great armies." The Karelians, or Karels, a Finnish

2 Synopsis of a paper read before the British Association (Anthropological Section) at Cardiff on August 27, 1920

No. 2672 , VOL. IO6] people, occupied most of the south-western shores of the White Sea in the fourteenth century. In the fifteenth century they ousted the Lapps from their homes on the western shore of the White Sea, driving them north into the Kola Peninsula. The country thus taken possession of by the Karels is now known as Karelia. But the name applied to it by Claudius Clavus was "Greenland."

To make it quite clear that Clavus referred solely to a European country when he spoke of "Greenland," it is necessary to keep in view the fact that in 1430 there was no European intercourse with the Greenland on the other side of the North Atlantic. The situation is definitely explained by Dr. Nansen, who states ("Encyc. Brit.," eleventh edition, vol. xii., pp. 542 and 548 ) that the last ship known to have visited the Norse colony in trans-Atlantic Greenland returned to Norway in $14 \mathrm{IO}$, and that from that date until ${ }_{1} 5_{5}^{8}$ the overseas Greenland was unvisited by Europeans and almost forgotten. It is therefore manifest that when any trustworthy writer of the period $1_{410^{-1} 5^{8} 5}$ makes reference to Greenlanders as people with whom Europeans are then in contact, he has in view a North European race, and not a race living on the other side of the Atlantic.

A further statement by Clavus has a distinct bearing upon this question. He tells us that to the west of the wild Lapps "are little pygmies, whom I have seen after they were taken at sea in a little skinboat, which is now [about 1430] hanging in the cathedral at Nidaros [i.e. Trondhjem]. There is likewise a long vessel of hides, which was also once taken with such pygmies in it." Again, Olaus Magnus relates how in ${ }^{1} 5^{\circ} 5$ he saw two of the leather skiffs of "the Greenland pirates" hanging in the cathedral at Oslo (Christiania). And Jacob Ziegler, in his work "Scondia" ( I $_{32}$ ), speaks of the "light boats of hide" of the Greenlanders. A complaint 
against "the Greenland pirates" in their " small ships without keels" is made in $155^{\text {I }}$ by Carsten Grip, Mayor of Kiel.

Visits of similar people in skin canoes are recorded in the Orkney Islands by writers of unimpeachable veracity in the seventeenth century. One of these canoes is still preserved in the anthropological museum of Marischal College, Aberdeen. Its framework and implements are made of North European wood. The estimated maximum height of its occupant is $4 \frac{1}{2} \mathrm{ft}$.

A vast field of conjecture opens up if we begin to consider the European skin boat in the first thousand years of the Christian era. Von Düben shows that it was the earliest boat used by the Lapps, and Prof. Julius Pokorny interprets the Fir Bolg of Gaelic lore as "skin-boat men." "The Greenlandish Attila Lay" is said to date from the eighth or ninth century.

\section{Prize Awards of the Paris Academy of Sciences.}

Mathematics.-Grand prize of the mathematical sciences to Ernest Esclangon, for his memoir entitled "New Researches on Quasi-periodic Functions"; the Poncelet prize to Elie Cartan, for the whole of his work; the Francœur prize to René Baire, for his work on the general theory of functions.

Mechanics.-A Montyon prize to Stéphane Drzewiecki, for his book on the general theory of the helix, with reference to marine and aerial propellerblades; the de Parville prize to Jean Villey, for his work on internal-combustion motors. No memoir was received dealing with the question proposed for the Fourneyron prize, but the arrears accrued are divided between Joseph Auclair and Alfred BoyerGuillon (rooo francs), for their theoretical and practical studies on the measurement of the acceleration of a point of a body subject to a periodic motion, and Eugene Burlot (10oo francs), for the whole of his work concerning the propagation of waves of shock in air and water.

Astronomy.-The Lalande prize to Léopold Schulhof, for his revision of the catalogue of the proper motions of $264 \mathrm{I}$ stars published by J. Bossert in 1896 ; the Valz prize to Ernest Maubant, for the whole of his work on the calculation of the perturbations of comets; the Janssen medal to William W. Coblentz, for his work on the infra-red radiation of terrestrial sources and of stars; the Pierre Guzman prize between François Gonnessiat (5000 francs), for his work on the photography of the minor planets, René Jarry-Desloges (5000 francs), for his physical observations on the planets, especially Mars, and Joanny-Ph. Lagrula (400o francs), for his work on the rapid identification of the minor planets. The Damoiseau prize was not awarded, and the questions proposed for I9I7 and 1920 are again proposed for 1923 .

Geography - The Delalande-Guérineau prize to Gearges Bruel, for the whole of his explorations and publications relating to French Equatorial Africa; the Tchihatchef prize to Auguste Chevalier, for his explorations in Africa and Indo-China; the Binoux prize to Marcel Augiéras, for his work in the western Sahara. The Gay prize is not awarded.

Navigation.--The prize of 6000 francs between Fernand Gossot (4000 francs), for his treatise on the effects of explosives, Pierre de Vanssay de Blavous (I500 francs), for the whole of his work, and René Risser (500 francs), for his work on ballistics; the Plumey prize between Charles Doyère (2000 francs), for the whole of his work, especially for the services which he rendered during the war, and Edouard Tournier (rooo francs), for his book entitled "Prac. tical Guide for the Use of Mechanics for Calculating the Internal Losses in Machines and Determining their Yield."

Physics.-The L. La Caze prize to Greorges Sagnac, for the whole of his work in physics; the Hébert prize to Léon Bouthillon, for his work and publications on wireless telegraphy; the Hughes prize to Frédéric Laporte, for his work on electrical standards and the photometry of electric lamps; the Clément
Felix foundation to Amédée Guillet, for his researches on chronometry.

Chemistry. - The Montyon prize (unhealthy trades) to Léonce Barthe, for his work on the hygiene of workshops, a mention ( $5_{500}$ francs) to Paul Goissedet, for his work in relation to poison gas, and a mention (Iooo francs) to Henri Guinot, for his chemical work during the war; the Jecker prize (5000 francs) between Henri Gault, for his work in organic chemistry, and Henri Hérissey, for his researches on the glucosides of plants; the L. La Caze prize to Robert de Forcrand, for the whole of his work in inorganic chemistry; the Cahours foundation between Raymond Cornubert, for his work in the cyclohexanone series, and Paul Robin, for his chemical studies in relation to the war and for his work on the oximes; the Houzeau prize to the late Emile Baud, for his researches on the compounds of aluminium and arsenic and his work in the national defence.

Mineralogy and Geology.-The Fontannes prize to Olivier Couffon, for his work entitled "Le Callovien du Chalet (Commune de Montreuil-Bellay)"; the Joseph Labbé prize to Albert Bordeaux, for his applications of geology to the solution of mining problems. The Victor Raulin prize is postponed until I92 I.

Botany.--The Desmazières prize to André Maublanc, for his work in mycology and plant diseases, an honourable mention to Pierre Sée, for his book on the diseases of paper; the De Coincy prize to Lucien Hauman-Merck, for the whole of his botanical work. The Montagne prize is not awarded.

Anatomy and Zoology.-The Cuvier prize to Alphonse Malaquin, for the whole of his work in zoology; the Savigny prize to F. Le Cerf, for his "Revision des Ægeriiclés algériens"; the Jean Thore nrize to A. Cros, for his biological studies of the Coleoptera of northern Africa.

Medicine and Surgery.-Montyon prizes to Pierre Delbet and Noël Fiessinger (2500 francs), for their memoir on the biology of war wounds, Joseph Franchini (2500 francs), for his studies on the pathogenic protozoa, and François Maignon (2500 francs), for his researches on the rôle of fats in the utilisation of albuminoids. Honourable mentions (I 50o francs) to Henri Alezais and Albert Peyron, for their researches on the histogenesis of certain groups of tumours, to Maurice Heitz-Boyer, for his researches on the physiology and surgery of bone, and to P. Lassablière, for his studies on milk and feeding of new-born infants. A citation to Joseph Rigaut and Antoine Orticoni, for their work entitled "L'évolution de la croissance chez les adénoïdiens "; the Barbier prize to Albert Berthelot, for his chemical work on intoxications of intestinal origin; the Bréant prize between Auguste Marie and Constantin Levaditi ( 3000 francs), for their work on general paralysis, and Henri Violle (2000 francs), for his memoir on cholera; the Godard prize to Henry Chabanier, for his study of the numerical laws of the renal secretion; the Mège prize is not awarded;

$$
\text { No. } 2672 \text {, VOL. IO6] }
$$

